\title{
The Value of Catur Purusa Artha and Capital Structure as The Maximization Key of Financial Performance in LPD Buleleng District
}

\section{Ni Luh De Erik Trisnawati ${ }^{*}$,, Gede Widiadnyana Pasek², Riana Dewi Kartika ${ }^{3}$}

1,2,3 Sekolah Tinggi Ilmu Ekonomi Satya Dharma Singaraja

\section{A R T I C L E I N F O}

Article history:

Received 19 May 2019

Received in revised form

16 June 2019

Accepted 15 July 2019

Available online 29 August 2019

Keywords:

Value of Catur Purusa Artha Capital Structure, Financial Performance

\begin{abstract}
A B S T R A C T
The purpose of this study is to examine the implementation of the value of Catur Purusa Arthaand capital structure, as the main foundation of business strategy to create maximum financial performance of LPD in Buleleng Regency. The study population was all active LPDs in Buleleng Regency. Sampling in this study using random sampling techniques to obtain as many as 60 observational data. The data analysis technique used in this research is the Component based SEM method, Partial Least Square (PLS). The results showed that the value of Catur Purusa Artha has a positive effect on Capital Structure and Financial Performance. Capital structure also has a positive effect on financial performance.
\end{abstract}

\footnotetext{
* Corresponding author.

E-mail addresses: eriktrisnanld@gmail.com (Ni Luh De Erik Trisnawati)
} 


\section{Introduction}

The Village Credit Institution (LPD) in Bali, which is a financial institution owned by Pakraman Village carries a big task in its mission to develop the economy of the village. In an effort to achieve these goals, the LPD then seeks to manage the full financial potential of the Pakraman village and seeks to find ways so that the financial function can be managed optimally. It is not only success in managing village finances but how the LPD can continue to struggle to maintain its existence. Especially when currently the industrial world is entering the era of free trade which indirectly becomes a driving force for business entities to always try to do their best to become the leader (Djuanda, 2016). The tasks carried out by the LPD become even harder when in the realization of operational activities it is still constrained in finding ways to conduct proper financial management. A strategy is needed so that the process of achieving these goals can be realized more easily. Creating a business strategy for LPDs requires a process and openness to adapt to LPD business conditions, which have a slightly different character from the business industry in general. The LPD was built as a financial institution owned by the local Pakraman village, which is also bound by customary law in force in the pakraman village. So that efforts to achieve these goals are not only directed towards the responsibility of the LPD business but the main responsibility is the responsibility to the local village. The success of LPD in achieving high financial performance is one of the efforts that can be done to realize the goal of building the village economy in accordance with the mission carried (Suandini, 2015).

The success of a company in achieving better financial performance and successfully improving its financial performance on an ongoing basis, is an achievement successfully demonstrated by the company in managing its funds (Gill et al, 2011). The company's financial management will be closely related to its capital structure. The choice of the right corporate capital structure will encourage better financial performance. Some researchers such as Nirajini and Priya (2013) and Ahmadand Abdullah (2012) have tested the choice of the company's capital structure on financial performance which found significant results. The company will achieve optimal financial performance if the combination of capital structure is right, because the decision in choosing the capital structure will cause fixed costs that will affect the financial performance achieved. Furthermore in 2013 Uzkurt et al found that the organizational culture adopted in a company affected the funding decisions and influenced the company's financial performance.

This finding is in line with what was revealed by Wiagustini (2011) that the courage of management in deciding using external funding sources which would certainly affect the results of the company's financial performance, was also influenced by the culture adopted in the company. Culture in the form of values, attitudes, beliefs and norms and views of life that prevails in society and adopted to be applied in a business organization will help encourage companies to achieve success and of course achieve better financial performance (Lee and $\mathrm{Yu}, 2004$ ). Organizational Culture is one of the non-financial components that affect a company's financial performance. This also may affect the financial performance of LPDs in Buleleng Regency in addition to their choice of capital structure. LPDs that are built and operate in Pakraman village area naturally have a touch of local cultural values in them and will indirectly affect every LPD activity. The culture adopted in the LPD will encourage LPD management to make more informed decisions on the LPD capital structure, so that this decision will affect the achievement of more optimal financial performance.

This study wants to explore the local cultural value of the Balinese people who are considered capable of improving financial performance, namely the the value of Catur Purusa Artha. The value of Catur Purusa Artha are the four goals of Balinese life as values that have been maintained until now as guidelines for the Hindus people in carrying out their life activities. The value of Catur Purusa Artha consists of Dharma, Artha, Kama and Moksa. Based on the concept of Resource Based View (RBV) Theory, if the value of Catur Purusa Artha is applied in a business entity, this value is an intangible asset for the company. The company's success in managing its intangible assets will affect its financial performance. The value of Catur Purusa Artha explains that the main foundation in managing a business is dharma (truth), this concept is almost similar to stewardship theory. As a new strategy in running a business that is more focused on serving the company's operational activities. Services based on Dharma (truth) will encourage the achievement of company goals. This concept will certainly be in accordance with the characteristics of the LPD as a village-owned financial institution that in each of its activities is confronting the village manners, so that if the LPD is managed on the basis of dharma (truth) and always strives to provide sincere services it will be able to achieve optimal financial performance. A business strategy that is able to encourage LPDs, especially in the Regency of Buleleng in order to realize their objectives, is very much needed, considering that until now LPDs are still found to be performing poorly. Even a few months ago in 2019, reported cases of embezzlement of LPD customer funds were reported again which showed the low performance of the LPD concerned. Data obtained through bulelengkab.go.id in the first quarter of 
2019 LPDs in Buleleng Regency were recorded as many as 169 units, of which 25 LPDs were categorized as quite healthy, 6 LPDs were not healthy, 7 LPDs were not healthy, 1 was just operating and as many as 25 LPDs were declared jammed.

These conditions indicate that the LPD in Buleleng Regency still needs the right strategy to be immediately implemented as a key strategy in improving the financial performance of the LPD. So the purpose of this research is to test the implementation of the value of Catur Purusa Artha and capital structure as the main foundation of business strategy to create maximum financial performance of LPD in Buleleng Regency.

\section{Methods}

The model in this study tries to predict causality between variables. Which examines the relationship between Value of Catur Purusa Artha, Capital Structure and LPD Financial Performance in Buleleng Regency. The development of this model is based on the consideration that it is still very necessary to conduct a test to create maximum financial management by combining financial aspects (capital structure) with non-financial aspects (Value of Catur Purusa Artha) in the LPD.

\section{A. Population and Sample}

This research was conducted on LPDs that are still active / operating in all of the Buleleng Regencies, which are spread across the Nine Districts. The research sample was taken using a random sampling technique with a total sample of $60 \mathrm{LPD}$.

\section{B. Research Variable}

This study uses value of Catur Purusa Artha as an exogenous variable. The value of Catur Purusa Artha is the four goals of Balinese life. This cultural value is still maintained until now which was then adopted and implemented in the LPD as a foundation in financial management to improve the financial performance of the LPD. The value of Catur Purusa Artha consists of four components, namely: Dharma (D), in business activities is reflected as the ability of company management to manage business activities internally. The management of internal business processes is realized through operational activities, customer management, and compliance with regulations.

Kama $(\mathrm{K})$ in business activities is an effort made to improve customer satisfaction, which is realized through: Competitive price quotes, providing timely services, maintaining product quality, and maintaining a partnership with customers, Artha (A), is the financial target set by the company to achieve which is realized through: carrying out efficient business activities, increasing sales volume and profits,; Moksa (M), in business activities is explained as the ultimate goal of a business that is increasing company value, this effort is realized through: achieving good corporate reputation, achieving business growth social responsibility to the community. The following Value of Catur Purusa Artha as a foundation for the LPD business strategy.

Table 1. The Value ofCatur Purusha Artaas the Basis of LPD Business Strategy

\section{The Value of Catur Purusha Artha}

The ultimate goal of a business is to increase business value that is realized through

Moksa business growth, good corporate reputation and corporate social responsibility and sustainable business capabilities

Artha The company's financial targets that are realized by the efficiency of the company's operational activities, increasing sales volume and conducting business development The efforts to increase customer satisfaction through adding new customers and maintaining old customer loyalty in order to continue to utilize the company's products

Kama / services. By considering price, quality, delivery time, strengthening relationships through relationships, good partnerships, and ongoing efforts to build the image of the institution

The ability to manage business in the form of a company's internal business processes

Dharma that is realized by operating activities, customer management, and compliance toward regulations 
Endogenous variables in this study is capital structure. Capital structure is the choice of LPDs in funding business operational activities carried out through debt and equity capital. The capital structure in this study uses three indicators that have been used by Wiagusini (2017) which include: percentage of total debt usage compared to total assets, percentage of total debt usage compared to total capital, percentage of long-term debt usage with total own capital.

The next endogenous variable is financial performance. Financial performance shows the success of LPD in using all resources efficiently and effectively in managing its finances. Financial Performance of LPD is reflected by three indicators which include: sales volume growth, profit growth, and asset growth (Wiagusini, 2017).

\section{Data Analisis Technique}

This study uses the types of primary data collected through the distribution of questionnaires to all LPD Chairpersons in Buleleng Regency. Data analysis technique used to test the hypothesis of this study is Structural Equation Modeling (SEM) with Partial Least Square (PLS) approach.

\section{Result and Discussion}

\section{A. The Hypothesis Test Result}

The result of data analysis using Structural Equation Modelling (SEM) with Partial Least Square (PLS) approach, the statistic test between variable (path) showed on Table 2.

Table 2. The Score of Statistic Test Correlation between Variable (Path Coefficient)

\begin{tabular}{lccccc}
\hline & $\begin{array}{c}\text { Oroginal } \\
\text { Sample (O) }\end{array}$ & $\begin{array}{c}\text { Sample } \\
\text { Mean } \\
\text { (M) }\end{array}$ & $\begin{array}{c}\text { Standard } \\
\text { Deviation } \\
\text { (STDEV) }\end{array}$ & $\begin{array}{c}\text { T } \\
\text { (O/ STDEV) }\end{array}$ & $\begin{array}{c}\text { Statistics } \\
\text { Value }\end{array}$ \\
\hline $\begin{array}{l}\text { The Value ofCatur Purusa Artha }-> \\
\begin{array}{l}\text { The Value ofCatur Purusa } \\
\text { Artha->Finacial Performance }\end{array}\end{array}$ & 0.691 & 0.716 & 0.086 & 9.451 & 0.000 \\
$\begin{array}{l}\text { Capital Structure->Finacial } \\
\text { Performance }\end{array}$ & 0.785 & 0.749 & 0.154 & 7.465 & 0.000 \\
\hline
\end{tabular}

Based on the results of the path coefficient above shows that the influence of the Value of Catur Purusa Artha on capital structure is significant as indicated by the value of T statistics $>1.96$ which is 9,451 or p-values is significant $<0.05$. The influence of the value of Catur Purusa Artha on financial performance shows a statistical $T$ value of 7,465 is greater than 1.96 with the score of p-value is significant $<0.05$. Similar results were obtained regarding the effect of capital structure on financial performance is significant with the score of T statistics $>1.96$ which is 6.138 with significant p-values $<0.05$.

\section{B. Discussion}

\section{a) The Effects of the Value of Catur Purusa Artha on the Capital Structure}

The test results indicate that the value of Catur Purusa Artha affects the capital structure. These findings support research previously conducted by Wiagustini on SMIs in Bali in 2017 that funding decisions are influenced by the cultural value of the Catur Purusa Artha applied by the company. In addition, several previous researchers who conducted an organizational culture test in general of funding decisions found similar results including Chui et al., (2002); Cao and Mauer, (2010) and Bhaird and Lucey, (2013).

PHDI (2013) describes the value of Catur Purusa Arthaas a touch of the local culture of the Balinese people, which provides guidance on the purpose of life and is still maintained today. This concept consists of Dharma, Artha, Kama and Moksa which are then applied in the business industry as a foundation for business management. The main basis is Dharma (truth), through the service attitude of the LPD to build better business processes in providing the best service to all LPD customers. Services that are carried out based on the dharma concept will satisfy customers, and this achievement will be the driving factor for achieving the final target set by the LPD. The choice of a more effective LPD funding source reflected through its capital structure is strongly influenced by the value of Catur Purusa Artha applied by the LPD. The chairman of the LPD will have a better basis for making choices in the capital structure. 


\section{b) The Effect of the Value of Catur Purusa Artha on Financial Performance}

The test results show that the application of the value of Catur Purusa Artha in LPD management affects financial performance. Stewardship theory explained by Donaldson and Davis provides the view that a business today, besides paying attention to financial factors should also pay attention to nonfinancial factors in its operational activities, which is more emphasis on service attitude. This concept is increasingly believed to be able to encourage better business management, when in 2013 PHDI said that one of the efforts that company could implement to improve its financial performance was through the application of the dharma concept as the main foundation in running the business. This was proven when Wiagustini conducted a study in 2017 that found the implementation of the Culture of Catur Purusa Arthaaffected the financial performance of SMIs in Bali. This test was then carried out in the LPD and it turned out that the value of Catur Purusa Artha was able to be the key to success in the LPD business strategy. The LPD was built with the main objective to prosper the local Balinese or Krama Desa community so that the concept of the the value of Catur Purusa Arthais very appropriate to be implemented as the main foundation for LPD financial management. This cultural value will guide the LPD management before deciding to carry out all LPD operational activities, always considering the impact and orienting towards long-term goals, maintaining a business reputation and sustainable business. So that the final goal to achieve more optimal financial performance can be achieved.

In line with several previous studies that examined the influence of organizational culture on financial performance which also found significant results including (Lee and Yu, 2004; Mazzi, 2011; Koszan et al. 2011; Anderson and Eshima, 2011) and Nold (2012). The Culture of Catur Purusa Artha concept is applied in LPD activities in Buleleng Regency, covering Dharma is an LPD internal business process carried out through good operational activities, managing LPD customers, and obeying government regulations that regulated in the Regional Regulations and the Customary Law of the Pakraman Village. Namely compliance with village'sawig-awig. Artha is a financial target that LPD wants to achieve through efficient implementation of activities, continuously striving to increase sales volume and business ventures to always innovate LPD service products. Kama is an effort taken by LPD in maintaining and increasing customer satisfaction by offering quality products and competitive prices, providing fast service and maintaining partnerships with customers. Moksa is the LPD's business goal of achieving business value improvement which is realized through efforts to increase profits, good business reputation and sustainable business capabilities (PHDI, 2013).

\section{c) The Effect of Capital Structure on the Finacial Performance}

The choice of the right capital structure is a combination of the choice of using debt or own capital which can improve the financial performance of LPDs. There are alternative choices in financing all operational activities of the company, the right choice will affect the achievement of better financial performance. The test results show that the capital structure affects the financial performance of the LPD. Companies that succeed in making a choice of a combination of their capital structure, will be able to improve their financial performance, because fixed costs in the form of capital costs incurred for these choices can be minimized (Hasnawati, 2005).

The level of risk to be faced by the company and fixed costs that will be borne by the company depends on the choice of the company's capital structure. The choice of the company's capital structure will certainly incur fixed costs and must be considered so that the company is able to make payments so that the company's liquidity is maintained. Conversely, if this condition is not a consideration in LPD decision making, it is not impossible that the company will experience difficulties so that it will affect the financial performance of the LPD. According to Nirajina and Priya (2013) Financial performance of a company can be improved one of them through making appropriate decisions on the choice of the company's capital structure.

The results of this study are in line with the results of previous studies conducted by Abor (2005), Gill et al. (2011), Toraman et al. (2013), Patel and Bhatt (2013), Gatsi (2012), Nirajini and Priya (2013) who found that corporate funding decisions were positively and significantly related to corporate financial performance.

\section{Conclusion}

Based on the research problem, objectives, theoretical basis, hypotheses and results of tests conducted, it can be concluded that: 1) The value of Catur Purusa Artha has a positive effect on Capital Structure. 2) The value of Catur Purusa Artha has a positive effect on Financial Performance. 3) Capital structure also has a positive effect on financial performance. 
The Implementation of the value of Catur Purusa Artha in the LPD business process provides a foundation in the form of dharma through service attitude, thus affecting the LPD management's decision in determining a more effective capital structure to achieve maximum financial performance.

\section{Reference}

Abor, Joshua., 2005. The effect of capital structure on profitability: empirical analysis of listed firms in Ghana.Journal of Risk Finance, Vol. 6, pp. 438-450.

Anderson, B.S, and Yoshihiro Eshima. 2011. The influence of firm age and intangible resources on the relationship between entrepreneurial orientation and firm growth among Jananese SMEs. Journal of Business Venturing. Vol.28, pp.413-429

Brigham, Eugene F. and Daves, Philip R. 2010.Intermediate Financial Management. 10 edition. Cengage Learning

Cao, Cathy Xuying and Mauer, David C. 2010.The Effect of Corporate Culture on CapitalStructure Policy.Available online at www.ssrn.com ssrn-id1571784. JEL ClassificationNumbers : G32, G34, M14 download atmarch, 01,2014.

Chong, H. Gin. 2008. Measuring Performance of Small-and Medium sized Entreprises : the grounded theory approach. Journal of Business and Public Affairs Vol.2, Issue 1

Chui, A.C.W., A.E. Lloyd, and C.C.Y. Kwok. 2002. The determination of capital structure: Isnational culture amissing piece to the puzzle? Journal of International Business Studies33(1): 99-127.

Djuanda, Vincentius David dan Josua Tarigan. 2016. Pengaruh Budaya Organisasi terhadap Kinerja Keuangan melalui Perilaku Manajer atas Isu Manajemen Lingkungan sebagai Variabel Interveningnya. Bussiness accounting review, vol 4, no 1, januari 2016 (61-72).

Gatsi, John Gartchie. 2012. Capital Structure of Ghanaian Banks : An Evaluation of Its Impacton Performance.The IUP Journal of Bank Management. Vol XI. Issue : 4 November.p.86-99

Gill, Amarjit., Biger, Nahum., Mathur, Neil., 2011. The Effect of Capital Structure on Profitability : Evidencefrom the United States. International Journal of Management, Vol. 28 No. 4 Part 1.

Kementrian Agama Republik Indonesia, Direktorat Jendral Bimbingan Masyarakat Hindu. 2010. DasarDasar Agama Hindu (Modul 1-16 PAH/3SKS).

Koentjaraningrat. 2008. Kebudayaan Mentalitas dan Pembangunan, Gramedia Pustaka Utama, Jakarta.

Kozan, M. Kamil, Dolun Oksoy, Onur Ozsoy. 2011. Owner Sacrifise and Small Business Growth. Journal of Word Business. 522: 1-11

Lee. S.K. dan Yu.K. 2004. Corporate Culture And Organization Performance, Journal OfManagerial

Mazzi, Chiara. 2011. Familly business and financial Performance: Current state of knowledge and future research challenges.Journal of Family Business Strategy, 2: 166-181

Nirajini, A and Priya, K B. 2013.Impact of Capital Structure on Financial Performance of theListed Trading Companies in Sri Lanka.International Journal of Scientific andResearch Publications, Volume 3, Issue 5, p.1-9

Nold, Herbert A. 2012. Linking knowledge processes with firm performance : organizationalculture. Journal of Intellectual Capital Vol. 13 No. 1, 2012 pp. 16-38

Parisada Hindu Dharma Indonesi (PHDI).2013. Mengejar Artha berdasarkan Dharma. Denpasar, Bali. 
Suandini, Kristina dan Leny Suzan. 2015. Pengaruh Struktur Modal Terhadap Kinerja Keuangan Persusahaan. Proceeding of Management : Vol.2, No.1

Susanto, A.B.; Sujanto, F.X.; Wijanarko, Himawan; Susanto, Patricia; Mertosona, Suwahjuhadi; dan Ismangil, Wagiono. 2008. A Strategic Management Approach Corporate Culture \& Organization Culture, The Jakarta Consulting Group, Jakarta.

Uzkurt, Cevahir ; Kumar, Rachna ; Kimzan, Halil Semih and Eminoglu, Gözde. 2013. Role of Innovation in theRelationship between Organizational Culture and Firm Performance : A Study of the Banking Sector in Turkey.European Journal of Innovation Management, Vol. 16 Issue : 1, p.92 - 117

Wiagustini, Ni Luh Putu. 2011. Peranan Budaya Hindu dalam Mengembangkan Kewirausahaan di Bali. JurnalWacana Ekonomi Vol 5, tahun 2010, Fakultas Ekonomi-Universitas Warmadewa.

Wiagustini, Ni Luh Putu, Ni Luh Anik Puspa Ningsih dan Luh Gede Sri Artini. 2017. Budaya "Catur Purusa Artha" Dan Orientasi Kewirausahaan Sebagai Basis Keputusan Pendanaan Dan Kinerja Keuangan. Prosiding Seminar Nasional AIMI. Jambi, 27 - 28 Oktober 2017.

Zheng, Xiaolan., Ghoul, Sadok El., Guedhami, Omrane and Kwok, Chuck C.Y. 2012. National Culture andCorporate Debt Maturity.Journal of Banking and Finance. Vol 36, Issue 2, pp.468-488 